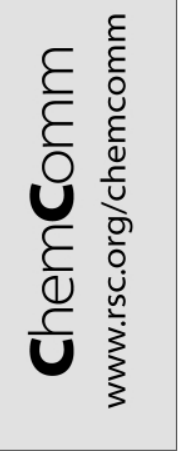

\title{
Luminescence-detected phase transitions in lanthanide-containing liquid crystals
}

\author{
Stéphane Suárez, ${ }^{a}$ Olimpia Mamula, ${ }^{a}$ Daniel Imbert, ${ }^{a}$ Claude Piguet ${ }^{b}$ and Jean-Claude G. Bünzli*a \\ a Swiss Federal Institute of Technology, Institute of Molecular and Biological Chemistry, \\ CH-1015-Lausanne, Switzerland. E-mail: jean-claude.bunzli@epfl.ch \\ ${ }^{b}$ University of Geneva, Department of Inorganic, Analytical and Applied Chemistry, 30 quai E. Ansermet, \\ CH-1211 Geneva 4, Switzerland
}

Received (in Cambridge, UK) 4th March 2003, Accepted 2nd April 2003

First published as an Advance Article on the web 28th April 2003

Complexes between lanthanide nitrates and a pro-mesogenic 18-membered diaza-substituted coronand are luminescent both as powders and liquid crystals (between 87 and 195 ${ }^{\circ} \mathrm{C}$ ), and the phase transitions are detected by monitoring luminescence intensity and lifetime.

Liquid crystals are the main components of new-generation cost-saving colour displays and a great deal of research effort has been devoted to their development during the last two decades. ${ }^{1}$ One disadvantage of these devices is their relatively low brightness, due to the use of polarisers and colour filters, and one way to overcome this shortcoming is the design of luminescent liquid crystals. While it is rather easy to find either photoluminescent sheets acting as filters or, even, organicbased luminescent liquid crystals, these materials display a broad-band, and usually blue, emission which is of little use in this context. On the other hand cathode-ray tubes rely on trichromatic phosphors emitting narrow bands in three basic colours, blue, green and red, and so do energy-saving luminescent lamps and tubes. Most of these phosphors contain rare-earth ions, $\mathrm{Eu}^{\mathrm{II}}$ (blue), $\mathrm{Tb}^{\mathrm{III}}$ (green) and $\mathrm{Eu}^{\mathrm{III}}$ (red). Henceforth the idea of introducing lanthanide ions in mesogenic phases. Metallomesogens are relatively new in the area of liquid crystals and they combine the properties of a liquid crystalline phase with the optical and magnetic properties of the metal ions they incorporate. The first liquid crystalline phase containing $\mathrm{Ln}^{\text {III }}$ ions was reported by Piechocki. ${ }^{2}$ Initially, it was thought that introducing bulky spherical ions in potentially mesogenic compounds could disrupt the required order to produce mesophases, but it turned out that many lanthanide-containing systems are amenable to form liquid crystalline phases, as reported in a recent comprehensive review article. ${ }^{3}$

Basically, there are two ways of designing luminescent lanthanide-containing mesophases. The first, historical, one is the introduction of highly luminescent complexes into known liquid crystalline phases and successful attempts with $\beta$ diketonates have been reported.4-7 The other one is the synthesis of luminescent complexes displaying mesogenic properties. ${ }^{8,9}$ Metal-centred luminescent properties, particularly those of $\mathrm{Eu}^{\mathrm{III}}$, have been taken advantage of to probe, at very low temperature, the degree of disorder around the metal ion in metastable liquid crystals based on europium laurate, ${ }^{8}$ and to determine the second-rank crystal-field parameter through analysis of the ${ }^{5} \mathrm{D}_{0} \rightarrow{ }^{7} \mathrm{~F}_{1}$ transition in order to assess the magnetic anisotropy of europium-containing metallomesogens. ${ }^{10,11}$ Here we present a new mesogenic class of luminescent lanthanide complexes built from a substituted diaza18-crown-6 macrocyclic ligand, and we show, for the first time, how luminescence intensity and lifetime can be used to monitor the transitions from crystalline to liquid crystalline phases and vice-versa.

Synthetic macrocycles are selective and versatile ligands for the complexation of trivalent lanthanide ions. With one exception where a steroid-substituted benzo-15-crown-5 ether has been reacted with lanthanide nitrates to yield highly viscous liquid crystalline phases, ${ }^{12}$ these ligands have not been investigated for the production of lanthanide-containing metallomesogens. Owing to the much better complexation ability of diaza-substituted crown ethers versus the all-ether ligands, ${ }^{13}$ we have chosen a diaza-18-crown-6, or (2.2), framework onto which mesogenic pendant arms have been grafted. Ligand L (see below) has been obtained according to a classical synthetic route in which the brominated arms are reacted with (2.2). $\dagger$

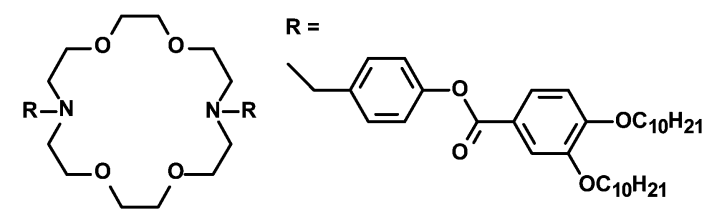

Complexes with formula $\left[\mathrm{Ln}\left(\mathrm{NO}_{3}\right)_{3} \mathrm{~L}\right] \cdot \operatorname{solv}(\mathrm{Eu}$ : solv $=0.25$ $\mathrm{H}_{2} \mathrm{O}$; Tb: 1thf) are obtained by refluxing a solution of $\mathrm{Ln}\left(\mathrm{NO}_{3}\right)_{3} \cdot n \mathrm{H}_{2} \mathrm{O}$ in acetonitrile or thf, to which is added a solution of $\mathrm{L}$ in methylene chloride. $\ddagger$

Thermal (TG and DSC, see Table 1) and polarized light microscopy (PLM) analyses of the ligand reveal a standard nonmesogenic behaviour with isotropisation occurring at $85^{\circ} \mathrm{C}$. On the other hand, the $\mathrm{Eu}^{\mathrm{III}}$ complex is clearly mesogenic. The first heating reveals loss of $0.25 \mathrm{H}_{2} \mathrm{O}$ per molecule and: (i) a $\mathrm{Cr} \rightarrow$ LC first order transition at $87^{\circ} \mathrm{C}$ with a $25^{\circ} \mathrm{C}$ hysteresis, (ii) a second exothermic and irreversible transformation at $124{ }^{\circ} \mathrm{C}$ which could correspond to a second order transition with partial disorganisation of the mesogenic phase and, (iii) isotropisation at $195-198^{\circ} \mathrm{C}$, immediately followed by decomposition. When temperatures higher than $170^{\circ} \mathrm{C}$ are avoided, the sample shows perfect reversibility, except for the transition at $124{ }^{\circ} \mathrm{C}$ which is no longer seen. PLM photographs (Fig. 1) display a birefringent fine texture with very small Schlieren's patterns. The latter texture corresponds neither to a nematic nor to a smectic A phase and its detailed characterization by X-ray diffraction measurements is in progress.

The Eu ${ }^{\mathrm{III}}$ complex has been analysed at low temperature by high-resolution laser-excited luminescence to probe the metal ion environment. Excitation spectra of the non-degenerate ${ }^{5} D_{0}$ $\leftarrow{ }^{7} \mathrm{~F}_{0}$ transition at $10 \mathrm{~K}$ evidence two components at 17268 (site I) and $\approx 17245 \mathrm{~cm}^{-1}$ (site II). Upon selective excitation, slightly different emission spectra are obtained which are dominated by the ${ }^{5} \mathrm{D}_{0} \rightarrow{ }^{7} \mathrm{~F}_{2}$ hypersensitive transition and which point, as expected, to a low symmetry around the $\mathrm{Eu}^{\mathrm{III}}$ ion. Population analysis performed on the magnetic dipole ${ }^{5} D_{0}$

Table 1 Thermal analysis data for the ligand and its complexes

\begin{tabular}{llrll}
\hline Compound & Transition & $T /{ }^{\circ} \mathrm{C}$ & $\begin{array}{l}\Delta H / \\
\mathrm{kJ} \mathrm{mol}^{-1}\end{array}$ & $\begin{array}{l}\Delta S / \\
\mathrm{J} \mathrm{mol}\end{array} \mathrm{K}^{-1} \mathrm{~K}^{-1}$ \\
\hline $\mathrm{L}$ & $\mathrm{Cr} \rightarrow \mathrm{I}$ & 85 & 99 & 275 \\
EuL & $\mathrm{Cr} \rightarrow \mathrm{LC}^{a}$ & 86 & 20 & 56 \\
& $\mathrm{LC} \rightarrow \mathrm{I}$ & 199 & - & - \\
$\mathrm{TbL}$ & $\mathrm{Cr} \rightarrow \mathrm{LC} a$ & 88 & 19 & 53 \\
& $\mathrm{LC} \rightarrow \mathrm{I}$ & n.a. & - &
\end{tabular}

${ }^{a}$ Liquid crystalline phase (possibly columnar). 


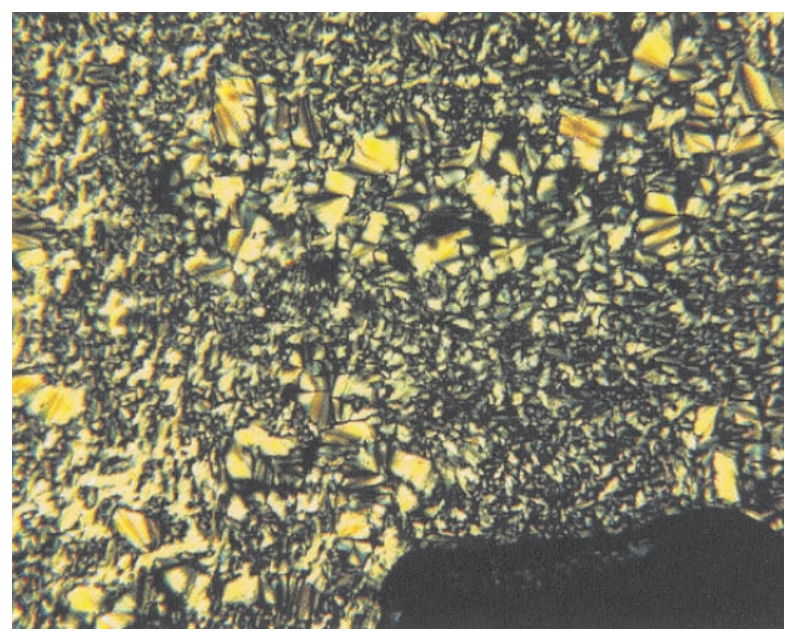

Fig. 1 Birefringent texture observed for $\left[\mathrm{Eu}\left(\mathrm{NO}_{3}\right)_{3} \mathrm{~L}\right] \cdot 0.25 \mathrm{H}_{2} \mathrm{O}$ at $110{ }^{\circ} \mathrm{C}$ (Leitz objective $20 \times / 0.40$, crossed polarizer and analyzer, Leica D300 F camera).

$\rightarrow{ }^{7} \mathrm{~F}_{1}$ transition shows site I representing $79 \pm 6 \%$ of the total Eu ${ }^{\mathrm{III}}$ population. The lifetime, $\tau$, of the $\mathrm{Eu}\left({ }^{5} \mathrm{D}_{0}\right)$ level amounts to about $1.1 \mathrm{~ms}$ for site I and $0.5 \mathrm{~ms}$ for site II. These data demonstrate that water interacts in the first coordination sphere of $\mathrm{Eu}^{\mathrm{III}}$ in site II and are in line with the loss of $0.25 \mathrm{H}_{2} \mathrm{O}$ evidenced in TG analysis. With the idea of testing how the luminescence properties of the $\mathrm{Eu}^{\mathrm{III}}$ ion vary during the phase transition, we have set up an experiment in which both the integrated intensity $I$ of the ${ }^{5} \mathrm{D}_{0} \rightarrow{ }^{7} \mathrm{~F}_{2}$ transition and the $\mathrm{Eu}\left({ }^{5} \mathrm{D}_{0}\right)$ lifetime are monitored versus temperature. $\S$ Generally speaking, increasing the temperature induces more nonradiative de-activation of the excited state and consequently, both the luminescence intensity and lifetime are expected to decrease according to an exponential law of the type $y=$ $y_{0} \cdot \mathrm{e}^{-C / R T} \cdot{ }^{14} \mathrm{We}$ have accordingly reported $\ln \left(\tau / \tau_{295}\right)$ and $\ln (I /$ $\left.I_{295}\right)$ versus the inverse of the absolute temperature on Fig. 2 to show that the phase transition intrinsically affects the luminescence parameters. Upon increasing the temperature, a sigmoid variation of both ratios is obtained. Crude mathematical analysis of these variations gives a transition temperature of 83 and $85{ }^{\circ} \mathrm{C}$, respectively. Equally interesting are the variations

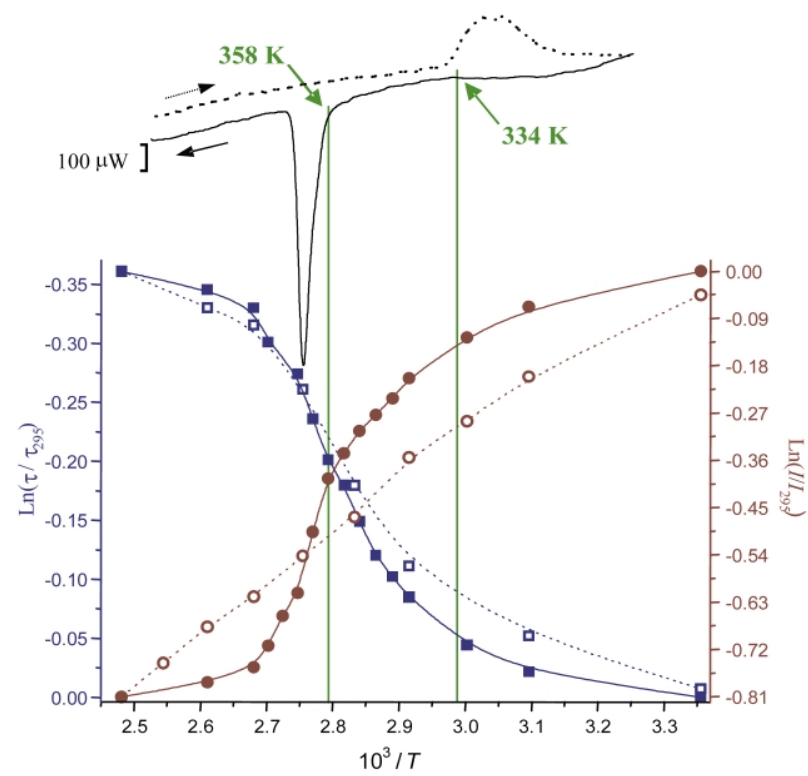

Fig. 2 Phase transition of $\left[\mathrm{Eu}\left(\mathrm{NO}_{3}\right)_{3} \mathrm{~L}\right] \cdot 0.25 \mathrm{H}_{2} \mathrm{O}$. (Top) DSC traces at $5{ }^{\circ} \mathrm{C}$ $\mathrm{min}^{-1}$. (Bottom) Integrated and corrected intensities of the $\mathrm{Eu}\left({ }^{5} \mathrm{D}_{0} \rightarrow{ }^{7} \mathrm{~F}_{2}\right)$ transition (right scale, O: from 298 to $403 \mathrm{~K}$, $\bigcirc$ : from 403 to $298 \mathrm{~K}$ excitation at $465.8 \mathrm{~nm})$; lifetimes of the $\operatorname{Eu}\left({ }^{5} \mathrm{D}_{0}\right)$ excited level, analyzing wavelength set on the maximum of the ${ }^{5} \mathrm{D}_{0} \rightarrow{ }^{7} \mathrm{~F}_{2}$ transition (left scale, from 298 to $403 \mathrm{~K}, \square$ : from 403 to $298 \mathrm{~K}$, excitation at $355 \mathrm{~nm}$ ). obtained while cooling the sample. The $\ln \left(\tau / \tau_{295}\right) v s .1 / T$ curve closely follows the variation measured upon heating, while the $\ln \left(I / I_{295}\right) v s .1 / T$ curve is almost linear. Sigmoid analysis of both curve yields 86 and $81{ }^{\circ} \mathrm{C}$, respectively, while DSC analyses display an hysteresis which is a function of the cooling rate $(25$ and $15{ }^{\circ} \mathrm{C}$ for rates equal to 5 and $0.1{ }^{\circ} \mathrm{C} \mathrm{min}-1$, respectively). This apparent discrepancy probably arises from the fact that luminescence measurements are made at thermal equilibrium while DSC data are recorded dynamically. The low- and hightemperature values of $\tau$ and $I$ are perfectly reproducible over tens of cycles.

In conclusion, this study demonstrates that the well-known EuIII luminescent probe ${ }^{14}$ can be used to accurately monitor a crystalline-to-mesogenic phase transition and that substituted diaza-18-crown-6 coronands are suitable pro-mesogenic ligands, as are other macrocycles for other metallomesogens. ${ }^{15}$ This opens the way to fascinating new developments in the field of lanthanide-containing liquid crystals.

This research is supported through grants from the Swiss National Science Foundation (National research program 47, Supramolecular Materials). We thank Mr Frédéric Gumy, Ms Hélène Lartigue and Dr Jean-Pierre Rivera for their technical help.

\section{Notes and references}

$\dagger$ Calc. for $\mathrm{C}_{80} \mathrm{H}_{126} \mathrm{~N}_{2} \mathrm{O}_{12}: \mathrm{C}, 73.5 ; \mathrm{H}, 9.7 ; \mathrm{N}, 2.1$. Found: $\mathrm{C}, 73.5 ; \mathrm{H}, 9.8$ $\mathrm{N}, 2.1 \%,{ }^{1} \mathrm{H}-\mathrm{NMR}\left(400 \mathrm{MHz}, \mathrm{CDCl}_{3}\right): \delta 0.90(\mathrm{~m}, 12 \mathrm{H}), 1.2-1.50(\mathrm{~m}, 56 \mathrm{H})$ $1.85(\mathrm{~m}, 8 \mathrm{H}), 2.86(\mathrm{~m}, 8 \mathrm{H}), 3.62-3.68(\mathrm{~m}, 16 \mathrm{H}), 3.72(\mathrm{~s}, 8 \mathrm{H}), 4.08(\mathrm{~m}, 8 \mathrm{H})$, $6.92(\mathrm{~d}, 3 \mathrm{~J}=8 \mathrm{~Hz}, 2 \mathrm{H}), 7.13(\mathrm{~d}, 3 \mathrm{~J}=8 \mathrm{~Hz}, 4 \mathrm{H}), 7.28(\mathrm{~d}, 3 \mathrm{~J}=8 \mathrm{~Hz}, 4 \mathrm{H})$ $7.67\left(\mathrm{~d},{ }^{4} \mathrm{~J}=2 \mathrm{~Hz}, 2 \mathrm{H}\right), 7.80\left(\mathrm{dd},{ }^{3} J=8,{ }^{4} \mathrm{~J}=2 \mathrm{~Hz}, 2 \mathrm{H}\right) \cdot{ }^{13} \mathrm{C}-\mathrm{NMR}$ $\left(\mathrm{CDCl}_{3}\right): \delta 14.1$ (primary C), 22.7-70.7 (secondary C), 111.9, 114.7, 121.4 $124.3,129.7$ (tertiary C), 121.7, 137.2, 148.6, 149.9, 153.7, 165.1 (quaternary C). ESI-MS (EtOH): $m / z$ 1307.86 $[\mathrm{L}+\mathrm{H}]^{+}($calc. 1307.89$) 30 \%$, $654.87[\mathrm{~L}+2 \mathrm{H}]^{2+}($ calc. 654.95$) 100 \%$.

$\ddagger$ Calc. for $\mathrm{C}_{80} \mathrm{H}_{126} \mathrm{~N}_{5} \mathrm{O}_{21} \mathrm{Eu} \cdot 0.25 \mathrm{H}_{2} \mathrm{O}$ : C, $58.2 ; \mathrm{H}, 7.7 ; \mathrm{N}, 4.2$. Found: $\mathrm{C}$, $58.0 ; \mathrm{H}, 7.6 ; \mathrm{N}, 4.2 \%$. Calc. for $\mathrm{C}_{80} \mathrm{H}_{126} \mathrm{~N}_{5} \mathrm{O}_{21}$ Tb.THF: C, $58.5 ; \mathrm{H}, 7.8 ; \mathrm{N}$, 4.1. Found: $\mathrm{C}, 58.5 ; \mathrm{H}, 8.1 ; \mathrm{N}, 4.1 \%$.

$\$ 2-3 \mathrm{mg}$ of the Eu complex were deposited between two quartz Suprasil ${ }^{\circledR}$ windows and a film was formed by slight friction. The sample was placed into a specially designed thermostatted cell holder operating in the range 20 to $250{ }^{\circ} \mathrm{C}\left( \pm 1{ }^{\circ} \mathrm{C}\right)$. A permanent stream of argon was flushed onto the sample to avoid decomposition. The sample was allowed to equilibrate for $10-15$ min before each measurement.

1 Handbook of Liquid Crystals, D. Demus, J. Goodby, G. W. Gray, H. W Spiess and V. Vill, eds., Wiley-VCH, Weinheim, 1998.

2 C. Piechocki, J. Simon, J.-J. André, D. Guillon, P. Petit, A. Skoulios and J. Weber, Chem. Phys. Lett., 1985, 122, 124.

3 K. Binnemans and C. Görller-Walrand, Chem. Rev., 2002, 102, 2303.

4 L. J. Yu and M. M. Labes, Appl. Phys. Lett., 1977, 31, 719.

5 J. Boyaval, F. Hapiot, C. Li, N. Isaert, M. Warenghem and P. Carette, Mol. Cryst. Liq. Cryst., 1999, 330, 1387.

6 J. Boyaval, C. Li, F. Hapiot, M. Warenghem, N. Isaert, Y. Guyot, G. Boulon and P. Carette, Mol. Cryst. Liq. Cryst., 2001, 359, 337.

7 K. Binnemans and D. Moors, J. Mater. Chem., 2002, 12, 3374.

8 R. W. Corkery and J. P. D. Martin, J. Lumin., 1999, 82, 1.

9 Y. G. Galyametdinov, L. Malykhina, W. Haase, K. Driesen and K. Binnemans, Liq. Cryst., 2002, 29, 1581

10 K. Binnemans, L. Malykhina, V. S. Mironov, W. Haase, K. Driesen, R. Van Deun, L. Fluyt, C. Gorller-Walrand and Y. G. Galyametdinov, ChemPhysChem, 2001, 2, 680.

11 Y. G. Galyametdinov, W. Haase, L. Malykhina, A. Prosvirin, I. Bikchantaev, A. Rakhmatullin and K. Binnemans, Chem. Eur. J., 2001, 7, 99

12 K. Binnemans and B. Gundogan, J. Rare Earths (China), 2002, 20, 249.

13 J.-C. G. Bünzli, in Handbook on the Physics and Chemistry of Rare Earths, K. A. Gschneidner, Jr. and L. Eyring, eds., Elsevier Science Publishers, Amsterdam, 1987, vol. 9, ch. 60, pp. 321-394.

14 J.-C. G. Bünzli, in Spectroscopic Properties of Rare Earths in Optical Materials, G. K. Liu and B. Jacquier, eds., Springer Verlag, Berlin, 2003 , ch. 11 , in press.

15 J. W. Goodby, G. H. Mehl, I. M. Saez, R. P. Tuffin, G. Mackenzie, R. Auzely-Velty, T. Benvegnu and D. Plusquellec, Chem. Commun., 1998, 2057. 